Benha Veterinary Medical Journal
Official Journal Issued by
Faculty of
Veterinary Medicine Journal homepage: https://bvmj.journals.ekb.eg/

Original Paper

\title{
Comparative study on the hygienic, production and economic indices of Japanese quails reared on floor and cage systems
}

\author{
Aya E. Azam1, Seham F. Shehata ${ }^{2}$, Liza S. Mohammed ${ }^{2, *}$, Eman A. Sallam ${ }^{3}$ \\ ${ }^{I}$ Animal Hygiene and Veterinary Management Department, Faculty of veterinary medicine Benha University, Benha 13736, \\ Egypt. \\ ${ }^{2}$ Veterinary Economics and Farm Management, Department of Animal Wealth Development, Faculty of veterinary medicine \\ Benha University, Benha 13736, Egypt \\ ${ }^{3}$ Animal and poultry production, Department of Animal Wealth Development, Faculty of veterinary medicine Benha University, \\ Benha 13736, Egypt.
}

\begin{tabular}{|c|c|}
\hline ARTICLE INFO & ABSTRACT \\
\hline $\begin{array}{l}\text { Keywords } \\
\text { Cage system } \\
\text { Economic indices } \\
\text { Floor system } \\
\text { Hygiene } \\
\text { Japanese quail } \\
\text { Performance } \\
\text { Received } 04 / 08 / 2021 \\
\text { Accepted } 01 / 09 / 2021 \\
\text { Available On-Line } \\
\text { 01/10/2021 }\end{array}$ & $\begin{array}{l}\text { The study was done on } 120 \text { newly hatched day-old chicks of brown Japanese quail obtained } \\
\text { from local Egyptian hatcheries, randomly divided into two groups. The } 1^{\text {st }} \text { group was reared } \\
\text { on cage system (CS), and the } 2^{\text {nd }} \text { group was reared on floor system (FS) ( } 60 \text { chicks per group/ } \\
\text { 3replicates, } 20 \text { chick/replicate), to investigate the effect of housing on the hygiene, } \\
\text { performance, survivability, and economic efficiency of quails. The results showed that the } \\
\text { total aerobic bacteria (TAB) of cloacal swabs had non-significant differences between CS, } \\
\text { and FS. The higher TAB, E. coli, and total fungal count (TFC) were recorded in FS in feed, } \\
\text { water, litter, and floor swabs samples, CS was more hygienic rearing system for quails. } \\
\text { Moreover, the higher TAB, E.coli, and lactobacillus were recorded in intestinal samples } \\
\text { collected from quails on FS (Log } 10 \text { CFU/g5.34, } 4.47 \text {, and } 3.96 \text {, respectively). There were no } \\
\text { significant difference in immunoglobulin G, interleukin } 2 \text { \&6, Malondialdehyde, Superoxide } \\
\text { Dismutase, and catalase activity between both rearing systems. Regarding performance } \\
\text { parameters, the higher body weight, and feed consumption were achieved in Japanese quails } \\
\text { reared on FS. Moreover, the rearing system had no significant influence on the performance, } \\
\text { and carcass traits. From the economic point of view, FS had higher feed cost, total variable } \\
\text { cost, total cost, and cost of each kg body weight gain from feed than those reared on CS. } \\
\text { While, the net profit, gross margin, benefit cost ratio, return on investment, and net profit for } \\
\text { each kg body weight gain were non-significantly higher in CS than FS. }\end{array}$ \\
\hline
\end{tabular}

\section{INTRODUCTION}

Housing system is one of the most crucial factors affecting poultry welfare, health, and production efficiency. In Egypt, as in most developing country, it is often difficult to reach the optimum performance, owing to several factors such as suboptimal housing. Environmental extremes, and stress conditions can be managed if the design of the poultry house is appropriate, and help in maximizing profitability (El-kholy et al., 2017).

The short generation interval, high biological meat value, and the particular taste, give the quail farming great importance in a densely populated country, besides minimum floor space, early market age, and the gainful quick business return (Nwogor and Ifeyinwa, 2017).

In the Floor system, the birds showed a state of freedom; express more of natural behavior through scratching in litter with safe rate of the living biota (FAO, 2013).
The problems of litter were vanished in cage system, competing with FS in quail farming. It dispenses with the litter, increases the production per unit area, reduces the labor $\cos t / \mathrm{m}^{2}$, and less effort for clean, and disinfection (Willis et al., 2001).

Nevertheless, obstacles of CS centered in the high costs of initial investment, the welfare depravation, the relative increase in mortality rates due to wing, and leg disorders, and the lack of exercise (Moravej, 2012).

The present study was conducted to investigate the effect of housing system on the bird hygiene, performance, livability of quails, and economic indices and to recommend the suitable management system.

\section{MATERIAL AND METHODS}

The experiment was conducted at the Center of Experimental Animal Research, Faculty of Veterinary

\footnotetext{
* Correspondence to: liza.reda@fvtm.bu.edu.eg
} 
Medicine, Benha University, Egypt, and was approved by the Institutional Animals Care, and Use committee Research Ethics Board, Faculty of Veterinary medicine, Benha University, under ethical number BUFVTM 03-221.

One hundred, and twenty newly hatched day-old chicks of brown Japanese quail obtained from local Egyptian hatcheries and incubated for 14days. The chicks were randomly selected, divided into two groups (60 chicks per group/ 3 replicates, 20 chick/replicate).The first group was raised on a CS provided with wire floor over galvanized trays with two feeders, and one drinker hanged separately outside the compartment. The second group of chicks was raised in three deep litter pens (FS) covered with sawdust sprinkled with slaked lime. The floor space in CS, and FS was recommended by (NRC, 2011) lists minimum space recommendations for quail as $7.6 \mathrm{~cm}^{2}$ floor area/bird.

All birds were allowed for 24 hours of artificial lighting, using one electric lamp (100 Watt), water, and feed ad libitum on balanced ration satisfying (NRC,1994) recommendations. The birds were vaccinated against ND disease at $2^{\text {nd }}$ week of the study duration.

2.1. Samples collection for microbiological examination: Six samples ( 2 sample/ replicate/ group) from water, feed, litter, cloaca, and nasal swabs) were collected weekly. $100 \mathrm{ml}$ of water, and $100 \mathrm{~g}$ of feed samples were collected, and prepared according to (Chowdhuri et al,. 2011).The litter samples were prepared according to (Mahmoud et al., 2014).Cloaca, and nasal cotton swab samples were collected, and prepared according to (Jones et al., 2015), and processed according to (García et al,. 2020). Samples from cecum were immediately collected, and processed at the end of experimental period according to (Sugiharto, 2016).

The appropriate dilutions were cultured and incubated overnight at $37^{\circ} \mathrm{C}$ for $\mathrm{TAB}$ (plate count agar-Lab M Limited),E.coli (chromogenic coliform agar-Oxoid Limited), and Lactobacillus(MRS agar-Lab M Limited), while incubated $2-5$ days at $25^{\circ} \mathrm{C}$ for TFC (Sabouraud dextrose agar-Oxoid Limited). Clostridium (Tryptose sulfite cycloserine agar-Lab M Limited) spp were anaerobically incubated.

\subsection{Biochemical analyses:}

At the end of the rearing period at 42 days, six blood samples from each treatment were taken in sterile tubes without anticoagulant for serum separation. The interleukins levels were measured by ELISA kit used according to the manufacturer's instructions. The levels of serum immunoglobulins (IgG and $\operatorname{IgM}$ ) were measured according to( Mancini et al., 1965), Superoxide Dismutase activity (SOD) was done according to Chanarin (1989), Malondialdehyde (MDA) was done according to Kei (1978), catalase activity according to Sinha (1972).

2.3. Growth performance and carcass traits:

Quails were weighed weekly from the beginning (at 14 days old) till the end of the rearing period (42 days old). The average bodyweight gain (BWG) was calculated weekly by subtract the previous week's weight from the average body weight. The difference between the offered feed weight, and the remainder part was used to compute feed consumption. The feed conversion ratio was calculated as total amount of feed divided by average body weight gain.

\subsection{Mortality percentage:}

Daily losses for each replicate were documented until the end of the rearing period (Faitarone et al., 2005).

\section{Carcass traits:}

At the end of the rearing period, the birds being fasted from feed, and given free access to water for around 12 hours, five birds were randomly selected from each group, weighed, slaughtered, dressed, and eviscerated. As a percentage of live weight, the dressing percentage was computed. The relative weights of internal organs to their live body weight were recorded separately (Badawi, 2017).

\subsection{Economic analysis:}

Collective economic efficiency measures that include:

2.5.1. Costs measures:

Total cost which calculated as summation of total variable cost (TVC), and total fixed cost .TVC include costs of chick price, feed cost (Surai and Fisinin, 2014), water, electricity, litter, and total veterinary management (TVM). The total fixed cost was calculated as depreciation value for building, and equipment's.

The total return (TR) was calculated by summation return from quails(bird weight per gram $X$ meat price per gram), and litter (Shehata et al., 2018).

Net profit (Santhosh and Singh, 2007) $=$ TR-TC.

Gross margin $(\mathrm{GM})=$ TR- TVC(EMOKARO and Eweka,2015).

Benefit cost ratio $(\mathrm{BCR})=$ total return $\div$ total cost

Return on investment $(\mathrm{ROI})=$ net profit $\div$ total cost

2.5.2. Partial economic efficiency measures which include: Cost of each $\mathrm{kg}$ body weight and body weight gain from feed (feed cost $\div$ BW, and feed cost $\div$ BWG).

Net profit from each $\mathrm{kg}$ body weight and body weight gain $(\mathrm{NP} \div \mathrm{BW}$, and $\mathrm{NP} \div \mathrm{BWG})$

\subsection{Statistical analysis:}

The data was analyzed using an independent sample $t$ test using SPSS software, V.16 (SPSS, 2007). Livability and mortality $\%$ were analyzed by cross tabulation.

\section{RESULTS}

The cloacal and nasal swabs showed non-significant differences in TAB between CS, and FS. Nasal swabs showed non-significant difference in E.coli, while the TFC showed significant differences between CS and FS along experimental period (Table1). However, the results cleared that there were significant increase in $\mathrm{TAB}$, E.coli, and TFC in FS than CS in feed, water, litter, and floor swab samples at $2^{\text {nd }}$ week, till end of the study duration.

Regarding the intestinal samples, higher TAB, E.coli and lactobacillus ( $\log _{10} \quad \mathrm{CFU} / \mathrm{g}$ 5.34, 4.47, and 3.96, respectively) counts were recorded in birds raised on the FS, while higher clostridia were recorded in those reared on the CS than FS (Log10 CFU/g4.90) (Fig.1).

The biochemical parameters (Fig. 2) showed nonsignificant differences in IgG, IL2, IL6, MDA, SOD, and catalase enzyme between both rearing systems, while IgM showed significant increase in CS compared to FS.

Regarding, growth performance traits (Table 2) for Japanese quails reared on CS, and FS. The weekly live body weight (LBW) was significantly $(\mathrm{P} \leq 0.05)$ higher in birds housed in FS at $3^{\text {rd }}$, and $5^{\text {th }}$ week of age(g 86.88, and 193.17, respectively)than those reared on CS. While it was not significantly differ between quails reared on different systems at 6th week age. 
In addition, the total feed consumption was significantly higher in quails reared on FS (g 779.65) than those reared on CS (g 692.74). However, the weekly body weight gain (BWG), and feed conversion rate were not significantly differing between groups along rearing period, except BWG in the period of $2^{\text {nd }}$ week to $3^{\text {rd }}$ week of age, and the FCR in the period of $3^{\text {rd }}$ to $4^{\text {th }}$ week of age were significantly higher in FS than CS group. Also, total FCR $\left(2^{\text {nd }}\right.$ week to $6^{\text {th }}$ week of age) was not significantly differ between the two groups.

Concerning carcass traits (dressing, liver, heart, and kidney percentages) (table 3 ) there were no significant differences between quails reared in the two different systems.

The results displayed in Table (4) showed a significant increase in feed cost (5.77 and 5.13 LE), total variable cost $(11.07$ and $9.83 \mathrm{LE})$,and total cost $(12.10$ and 11.09 LE)for Japanese quails reared on FS than those reared on $\mathrm{CS}$, respectively. On the other hand, TR was not significantly higher in FS than CS, while, NP, GM, BCR, and ROI, NP/BW, and NP/BWG were not significantly higher in CS than FS. Finally, the cost of each kg body weight gain from feed was significant higher in FS (25.67 LE) than CS (23.56 LE).

\section{DISCUSSION}

The type of the house has direct effect on hygienic status of quails, as the different housing facilities (feeders, drinkers, litter/wire floor, equipment's) shedding different number of microorganisms. The higher feed, water, and litter bacterial contamination were recorded at the $4^{\text {th }}$ week of the study duration in FS than CS, a result that agreed with (Trawińska et al., 2016)they reported that the highest bacterial count in the litter was detected at the late rearing period of birds.

The significant increases in bacterial load (TAB, E.coli, and TFC) in feed, water, litter, and nasal swabs were from living birds reared on FS might be due to open feed troughs, and drinkers that easily to be contaminated with litter, birds, dust, and fecal matter (Ezekiel et al., 2011). The contaminated feed is one of animals bacterial, and fungal sources, which has a health concerns socioeconomic impact not only on the birds, but also on consumers (Rosemary et al., 2013).

The nasal swab samples showed significant differences between FS, and CS, those results agreed with Al-Bahouh et al. (2012), who found that using cage provide better hygienic condition that could lead to improving the health, and quality of birds.

From the results of cecum microbial count, it was found that there was a significant $(\mathrm{P} \leq 0.05)$ difference on intestinal $\mathrm{TAB}$ and E.coli counts, and no significance on intestinal clostridia, and lactobacillus count between quails reared on CS, and FS (Fig.1).

Table 1. Total aerobic bacteria, E. coli and Total fungal count in Japanese quails reared on cages system (C. S.) vs floor system (F. S.)

\begin{tabular}{|c|c|c|c|c|c|c|c|c|c|c|}
\hline \multicolumn{11}{|c|}{ Total aerobic bacteria } \\
\hline & \multicolumn{2}{|c|}{ Cloacal swabs } & \multicolumn{2}{|l|}{ Nasal swabs } & \multicolumn{2}{|c|}{ Litter $\backslash$ floor swabs } & \multicolumn{2}{|l|}{ Feed } & \multicolumn{2}{|l|}{ Water } \\
\hline & C.S. & F.S. & C.S. & F.S. & C.S. & F.S. & C.S. & F.S. & $\begin{array}{ll}\text { C.S. } \\
\end{array}$ & F.S. \\
\hline $1^{\text {st }}$ week & $3.35^{\mathrm{a}} \pm 0.26$ & $3.46^{\mathrm{a}} \pm 0.24$ & $2.00^{\mathrm{a}} \pm 0.33$ & $1.82^{\mathrm{a}} \pm 0.41$ & $1.67^{\mathrm{a}} \pm 0.33$ & $2.22^{\mathrm{a}} \pm 0.08$ & $3.53^{a} \pm 0.09$ & $3.54^{\mathrm{a}} \pm 0.15$ & $1.20^{\mathrm{a}} \pm 0.17$ & $1.24^{\mathrm{a}} \pm 0.10$ \\
\hline $2^{\text {nd }}$ week & $3.76^{\mathrm{a}} \pm 0.30$ & $4.55^{\mathrm{a}} \pm 0.40$ & $3.09^{\mathrm{a}} \pm 0.22$ & $3.37^{\mathrm{a}} \pm 0.06$ & $3.35^{\mathrm{b}} \pm 0.15$ & $3.81^{\mathrm{a}} \pm 0.06$ & $4.33^{b} \pm 0.10$ & $4.74^{\mathrm{a}} \pm 0.07$ & $3.19^{b} \pm 0.05$ & $4.25^{\mathrm{a}} \pm 0.08$ \\
\hline $3^{\text {rd }}$ week & $4.60^{\mathrm{a}} \pm 0.11$ & $5.23^{\mathrm{a}} \pm 0.42$ & $3.64^{\mathrm{a}} \pm 0.07$ & $3.81^{\mathrm{a}} \pm 0.11$ & $3.61^{b} \pm 0.12$ & $4.13^{\mathrm{a}} \pm 0.09$ & $4.72^{b} \pm 0.04$ & $5.47^{\mathrm{a}} \pm 0.19$ & $4.39^{b} \pm 0.06$ & $4.78 \mathrm{a} \pm 0.05$ \\
\hline $4^{\text {th }}$ week & $5.22^{\mathrm{a}} \pm 0.10$ & $5.68^{a} \pm 0.18$ & $3.94^{\mathrm{b}} \pm 0.07$ & $4.40 \mathrm{a} \pm 0.07$ & $4.23^{\mathrm{b}} \pm 0.09$ & $4.63^{\mathrm{a}} \pm 0.09$ & $4.91^{b} \pm 0.03$ & $5.59^{\mathrm{a}} \pm 0.12$ & $4.61^{b} \pm 0.06$ & $5.20^{\mathrm{a}} \pm 0.08$ \\
\hline \multicolumn{11}{|l|}{ E.coli } \\
\hline $1^{\text {st }}$ week & $2.92^{\mathrm{a}} \pm 0.21$ & $2.36^{\mathrm{a}} \pm 0.63$ & 0.00 & 0.00 & $0.00^{\mathrm{b}}$ & $1.32^{\mathrm{a}} \pm 0.35$ & 0.00 & 0.00 & 0.00 & 0.00 \\
\hline $2^{\text {nd }}$ week & $3.52^{\mathrm{a}} \pm 0.20$ & $3.84^{\mathrm{a}} \pm 0.06$ & $1.43^{\mathrm{a}} \pm 0.72$ & $2.75^{\mathrm{a}} \pm 0.14$ & $4.73^{\mathrm{a}} \pm 0.05$ & $4.83^{\mathrm{a}} \pm 0.14$ & $3.37^{b} \pm 0.19$ & $5.52^{\mathrm{a}} \pm 0.04$ & $1.56^{\mathrm{b}} \pm 0.55$ & $5.53^{\mathrm{a}} \pm 0.11$ \\
\hline $3^{\text {rd }}$ week & $5.36^{\mathrm{a}} \pm 0.17$ & $5.33^{\mathrm{a}} \pm 0.33$ & $3.09^{\mathrm{a}} \pm 0.35$ & $3.74^{\mathrm{a}} \pm 0.08$ & $5.28^{\mathrm{a}} \pm 0.03$ & $5.79^{\mathrm{a}} \pm 0.27$ & $4.72^{\mathrm{b}} \pm 0.12$ & $5.95^{\mathrm{a}} \pm 0.05$ & $2.59^{\mathrm{b}} \pm 0.15$ & $5.91^{\mathrm{a}} \pm 0.06$ \\
\hline $4^{\text {th }}$ week & $5.47^{\mathrm{a}} \pm 0.14$ & $5.48^{\mathrm{a}} \pm 0.29$ & $3.72^{\mathrm{a}} \pm 0.19$ & $4.14^{\mathrm{a}} \pm 0.09$ & $5.71^{\mathrm{a}} \pm 0.06$ & $5.94^{\mathrm{a}} \pm 0.31$ & $5.50^{\mathrm{b}} \pm 0.02$ & $6.11^{\mathrm{a}} \pm 0.10$ & $3.18^{\mathrm{b}} \pm 0.10$ & $5.96^{\mathrm{a}} \pm 0.06$ \\
\hline \multicolumn{11}{|c|}{ Total fungal count } \\
\hline $1^{\text {st }}$ week & $4.06^{\mathrm{a}} \pm 0.52$ & $4.07^{\mathrm{a}} \pm 0.52$ & 0.00 & 0.00 & $0.00^{\mathrm{b}}$ & $1.37^{\mathrm{a}} \pm 0.05$ & $1.44^{\mathrm{a}} \pm 0.32$ & $1.43^{\mathrm{a}} \pm 0.35$ & 0.00 & 0.00 \\
\hline $2^{\text {nd }}$ week & $4.67^{\mathrm{a}} \pm 0.08$ & $4.73^{\mathrm{a}} \pm 0.08$ & $0.00^{\mathrm{b}}$ & $3.59^{\mathrm{a}} \pm 0.14$ & $3.20^{\mathrm{b}} \pm 0.14$ & $4.67^{\mathrm{a}} \pm 0.09$ & $2.32^{b} \pm 0.31$ & $4.39^{\mathrm{a}} \pm 0.09$ & $2.35^{\mathrm{b}} \pm 0.42$ & $4.16^{\mathrm{a}} \pm 0.12$ \\
\hline $3^{\text {rd }}$ week & $4.74^{\mathrm{a}} \pm 0.33$ & $5.15^{\mathrm{a}} \pm 0.10$ & $0.00^{\mathrm{b}}$ & $1.57^{\mathrm{a}} \pm 0.34$ & $3.38^{b} \pm 0.12$ & $5.51^{\mathrm{a}} \pm 0.08$ & $2.76^{\mathrm{b}} \pm 0.21$ & $5.40^{\mathrm{a}} \pm 0.19$ & $3.54^{\mathrm{b}} \pm 0.23$ & $4.61^{\mathrm{a}} \pm 0.09$ \\
\hline $4^{\text {th }}$ week & $5.01^{\mathrm{a}} \pm 0.20$ & $5.33^{\mathrm{a}} \pm 0.34$ & $0.00^{\mathrm{b}}$ & $2.94^{\mathrm{a}} \pm 0.10$ & $3.81^{b} \pm 0.18$ & $5.85^{\mathrm{a}} \pm 0.04$ & $3.27^{b} \pm 0.04$ & $5.61^{\mathrm{a}} \pm 0.10$ & $3.77^{\mathrm{b}} \pm 0.14$ & $5.36^{\mathrm{a}} \pm 0.09$ \\
\hline
\end{tabular}

Table 2 Growth performance traits in Japanese quails reared on cages system vs floor system

\begin{tabular}{lrrr}
\hline system vs floor system & Variables & Cages system & \multicolumn{1}{c}{ Floor system } \\
\hline Body weight changes (g) & $2^{\text {nd }}$ week & $52.00^{\mathrm{a}} \pm 1.53$ & $53.67^{\mathrm{a}} \pm 1.86$ \\
& $3^{\text {rd }}$ week & $77.92^{\mathrm{b}} \pm 0.89$ & $86.88^{\mathrm{a}} \pm 2.72$ \\
& $4^{\text {th }}$ week & $138.87^{\mathrm{a}} \pm 3.49$ & $148.85^{\mathrm{a}} \pm 3.56$ \\
& $5^{\text {th }}$ week & $185.04^{\mathrm{b}} \pm 2.21$ & $193.17^{\mathrm{a}} \pm 1.34$ \\
& $6^{\text {th }}$ week & $217.60^{\mathrm{a}} \pm 2.17$ & $224.85^{\mathrm{a}} \pm 4.59$ \\
\hline Body weight gain (g) & $2-3$ week & $25.92^{\mathrm{b}} \pm 0.72$ & $33.21^{\mathrm{a}} \pm 1.94$ \\
(BWG) & $3-4$ week & $60.95^{\mathrm{a}} \pm 2.68$ & $61.98^{\mathrm{a}} \pm 0.92$ \\
& $4-5$ week & $46.17^{\mathrm{a}} \pm 4.09$ & $44.32^{\mathrm{a}} \pm 4.88$ \\
& $5-6$ week & $32.55^{\mathrm{a}} \pm 3.56$ & $31.68^{\mathrm{a}} \pm 4.08$ \\
& Total gain & $165.60^{\mathrm{a}} \pm 1.88$ & $171.19^{\mathrm{a}} \pm 5.05$ \\
\hline Feed consumption (g) (FC) & $2-3$ week & $155.67^{\mathrm{b}} \pm 2.33$ & $167.33^{\mathrm{a}} \pm 1.45$ \\
& $3-4$ week & $166.68^{\mathrm{b}} \pm 7.02$ & $222.84^{\mathrm{a}} \pm 3.83$ \\
& $4-5$ week & $181.99^{\mathrm{a}} \pm 4.45$ & $193.70^{\mathrm{a}} \pm 7.67$ \\
& $5-6$ week & $188.41^{\mathrm{a}} \pm 5.89$ & $195.77^{\mathrm{a}} \pm 6.06$ \\
& Total feed & $692.74^{\mathrm{b}} \pm 17.83$ & $779.65^{\mathrm{a}} \pm 13.10$ \\
\hline Feed conversion rate & $2-3$ week & $6.02^{\mathrm{a}} \pm 0.26$ & $5.04^{\mathrm{a}} \pm 0.31$ \\
(FCR) & $3-4$ week & $2.74^{\mathrm{b}} \pm 0.01$ & $3.60^{\mathrm{a}} \pm 0.08$ \\
& $4-5$ week & $3.94^{\mathrm{a}} \pm 0.37$ & $4.37^{\mathrm{a}} \pm 0.37$ \\
& $5-6$ week & $5.80^{\mathrm{a}} \pm 0.72$ & $6.18^{\mathrm{a}} \pm 0.79$ \\
\hline Total FCR & & $4.18^{\mathrm{a}} \pm 0.12$ & $4.56^{\mathrm{a}} \pm 0.09$ \\
Livability \% & $96.70 \%$ & $93.30 \%$ \\
Mortality \% & & $3.30 \%$ & $6.70 \%$ \\
\hline Means carrying a-b significantly differ (P $\leq 0.05$ ) among different housing systems
\end{tabular}

Table 3 Carcass traits in Japanese quails reared on cages system vs floor system

\begin{tabular}{|c|c|c|}
\hline Variables & Cage system & Floor system \\
\hline Dressing $\%$ & $70.44^{\mathrm{a}} \pm 0.43$ & $68.59^{\mathrm{a}} \pm 0.83$ \\
\hline Liver \% & $1.98^{\mathrm{a}} \pm 0.07$ & $2.06^{\mathrm{a}} \pm 0.07$ \\
\hline Heart \% & $1.09^{\mathrm{a}} \pm 0.05$ & $1.11^{\mathrm{a}} \pm 0.07$ \\
\hline Intestine \% & $4.51^{\mathrm{a}} \pm 0.27$ & $5.08 \mathrm{a} \pm 0.79$ \\
\hline \multicolumn{3}{|c|}{$\begin{array}{l}\text { Means carrying }{ }^{\text {a-b }} \text { significantly differ }(\mathrm{P} \leq 0.05) \text { among different housing systems } \\
\text { Table } 4 \text { Economic indices in Japanese quails reared on cages system vs floo } \\
\text { system }\end{array}$} \\
\hline Variables & Cages system & Floor system \\
\hline Feed cost & $5.13^{b} \pm 0.13$ & $5.77^{\mathrm{a}} \pm 0.10$ \\
\hline Chick price & 3.30 & 3.30 \\
\hline Total fixed cost & 1.26 & 1.03 \\
\hline Labor & 0.85 & 0.85 \\
\hline Total veterinary management & 0.40 & 0.40 \\
\hline Water & 0.15 & 0.15 \\
\hline Litter cost & 0.00 & 0.60 \\
\hline Total variable cost (TVC) & $9.83^{\mathrm{b}} \pm 0.13$ & $11.07^{\mathrm{a}} \pm 0.10$ \\
\hline Total cost (TC) & $11.09^{b} \pm 0.13$ & $12.10^{\mathrm{a}} \pm 0.10$ \\
\hline Return from litter & 0.00 & 0.35 \\
\hline Return from quail selling & $13.06^{\mathrm{a}} \pm 0.13$ & $13.49^{\mathrm{a}} \pm 0.28$ \\
\hline Total return (TR) & $13.06^{\mathrm{a}} \pm 0.13$ & $13.84^{\mathrm{a}} \pm 0.28$ \\
\hline Gross margin & $3.23^{\mathrm{a}} \pm 0.11$ & $2.77^{\mathrm{a}} \pm 0.24$ \\
\hline Net profit (NP) & $1.97^{\mathrm{a}} \pm 0.11$ & $1.74^{\mathrm{a}} \pm 0.24$ \\
\hline Benefit cost ratio & $1.18^{\mathrm{a}} \pm 0.01$ & $1.14^{\mathrm{a}} \pm 0.02$ \\
\hline Return on investment & $0.18^{\mathrm{a}} \pm 0.01$ & $0.14^{\mathrm{a}} \pm 0.02$ \\
\hline Feed cost / body weight $\mathrm{Kg}$ & $23.56^{b} \pm 0.47$ & $25.67^{\mathrm{a}} \pm 0.46$ \\
\hline Feed cost / body weight gain & $30.96^{\mathrm{a}} \pm 0.87$ & $33.73^{\mathrm{a}} \pm 0.64$ \\
\hline NP / body weight gain kg & $11.88^{\mathrm{a}} \pm 0.51$ & $10.13^{\mathrm{a}} \pm 1.18$ \\
\hline $\mathrm{NP} /$ body weight $\mathrm{kg}$ & $9.05^{\mathrm{a}} \pm 0.45$ & $7.71^{\mathrm{a}} \pm 0.91$ \\
\hline
\end{tabular}


These results agreed with (Yan et al., 2020) who said that that floor rearing usually leads to a richer gut microbiota than other systems.

The environmental conditions could alter the gut microbiota, as the FS usually leads to a richer, and more diverse gut microbiota than other systems (Cui et al., 2017).While our results disagreed with (Li et al., 2017).

Regarding biochemical parameters, there was a nonsignificant difference in IgG, IL2, IL 6, MDA, SOD, and catalase between both rearing systems, while IgM showed significant increase in CS compared to FS. Antioxidant activity had no significant difference between both systems, in agreement with (Şimşek et al., 2014) except the values of MDA. The results of immunoglobulins were in agreement with (Darwish et al., 2017)

In the current study, we found that LBW was not significantly different between quails reared on both systems at end of rearing period. The weekly body weight gain $\left(3^{\text {rd }}-4^{\text {th }}, 4^{\text {th }}-5^{\text {th }}\right.$, and $5^{\text {th }}-6^{\text {th }}$ week $)$, and total body weight gain were not significantly different between the two systems; a result that was in accordance with (Badawi, 2017). However, the results disagreed with (Razee et al., 2016), who discovered that quails raised in battery cages had much larger final body weight than those raised in a floor pen

The total feed consumption by quails reared on FS was significantly higher than those reared on CS. These results were nearly similar to Ayorinde, (1994). On country to our result Razee et al. (2016)reported that quails reared on floor had consumed less feed comparing with those reared on cage.

The total FCR $\left(2^{\text {nd }}\right.$ to $6^{\text {th }}$ week of age $)$ was not significantly different between quails reared on both systems. Our result was agreed with, (Padmakumar et al., 2000)who found FCR variation was shown to be non-significant in cage and litter reared birds. Our result disagreement with (Razee et al., 2016) as they record that FCR at $2^{\text {nd }}, 3^{\text {rd }}$, and $5^{\text {th }}$ week of quails reared on floor pen was significantly greater than those reared in cage rearing system.

There was no significant difference between quails reared on two different rearing systems in carcass traits (dressing, liver, heart, and kidney percentage). Our findings indicated insignificant difference between FS and CS on livability, and mortality percentages. These results were in accordance with(Badawi, 2017).

Economic analysis revealed that, rearing quails on FS had higher Feed cost, TVC, and total cost than those reared on CS. This might be due to higher feed consumed for FS birds that was reflected on feed cost, total variable cost, and total cost. This could be attributed to increased feed consumption in FS than CS (Abo Ghanima et al., 2020). The TR and cost of each kg body weight from feed was significantly higher in FS than CS. While NP, GM, BCR, ROI, NP/BW, and NP/BWG were non-significantly higher in CS than FS, this could be due to the non-significance increase in BW in FS than CS, this result was in agreement with (Badawi, 2017), and increasing feed cost in FS than CS, a finding that was in agreement with (Abo Ghanima et al., 2020).

\section{CONCLUSION}

From the results of this study, it is concluded that the CS were more hygienic rearing system for quails than FS, while the higher body weight, and feed consumption were achieved in Japanese quails reared on FS. Moreover, the rearing system had no significant influence on the performance, and carcass traits. From the economic point of view, there were no significant difference in the total return, gross margin, net profit for both birds housed either on floor or cage systems.

\section{CONFLICT OF INTEREST}

The authors declare that they have no conflicts of interest for current data

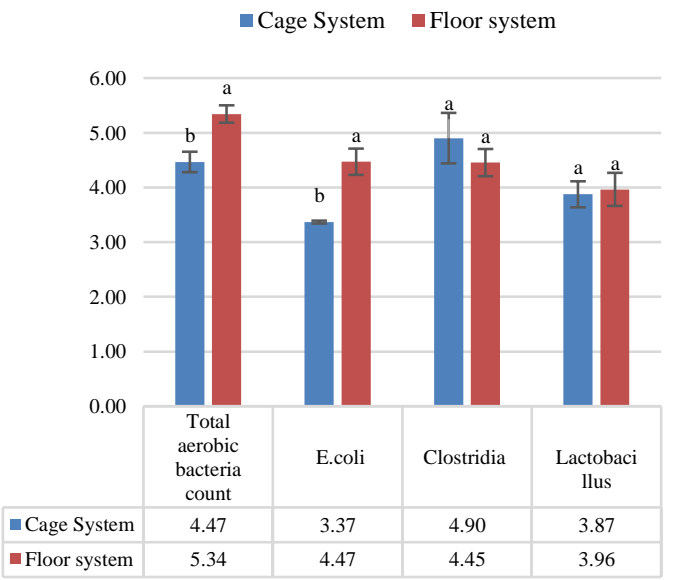

Fig 1 Total aerobic bacteria, E. coli, clostridia, and lactobacillus ( $\log _{10}$ $\mathrm{CFU} / \mathrm{g}$ ) in Japanese quail reared on cage system and floor system. Means carrying ${ }^{\mathrm{a}-\mathrm{b}}$ significantly differ $(\mathrm{P} \leq 0.05)$ among different housing systems

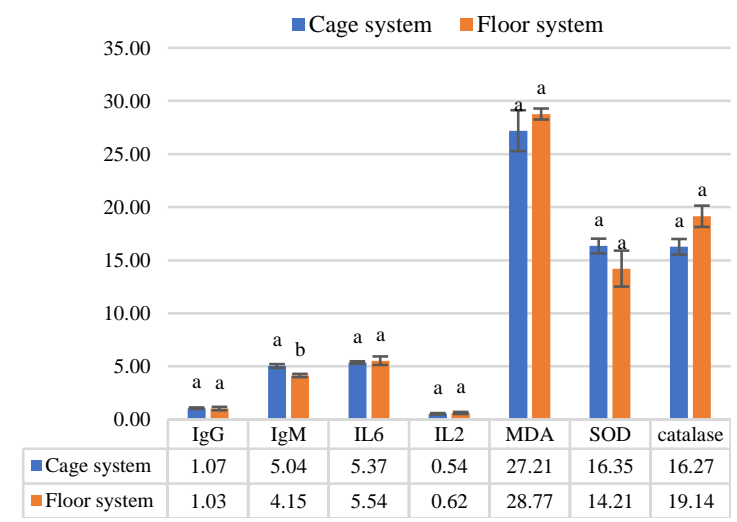

Fig 2 Biochemical parameters in Japanese quail reared on cages system vs. floor system. IgG (Immunoglobulin G), IgM (Immunoglobulin M), IL6 (Interleukin 6), IL2 (Interleukin 2), MDA (Malondialdehyde), SOD (Superoxide Dismutase activity). Means carrying same letter nonsignificant. Means carrying ${ }^{\text {a-b }}$ significantly differ $(\mathrm{P} \leq 0.05)$ among different housing systems

\section{REFERENCES}

1. Abo Ghanima, M. M., Abd El-Hack,M.E, Othman,S.I.,Taha,A.E., Allam,A.A. and Abdel-Moneim,A.E. 2020. "Impact of Different Rearing Systems on Growth, Carcass Traits, Oxidative Stress Biomarkers, and Humoral Immunity of Broilers Exposed to Heat Stress." Poultry Science, 99 (6): 3070-78

2. Al-Bahouh, M. E., A., Al-Nasser, F. K., Abdullah, G.R., and Magdy M. M. 2012. "Production Performance of Different Broiler Breeds under Different Housing Systems." International Journal of Poultry Science, 11 (3): 190-95.

3. Ayorinde, K. L. 1994. Evaluation of the growth and carcass characteristics of the Japanese quail (Coturnix Conturnix Japonica) in Nigeria. Nigerian Journal of Animal Production 15 (January): 119-26.

4. Badawi, Y. 2017. Effect of housing system on Japanese quai performance. Journal of Animal and Poultry Production 8 (12): 483-90. 
5. Chanarin, I. 1989. Laboratory Haematology: An Account of Laboratory Techniques. Edinburgh: Churchill Livingstone.

6. Chowdhuri, A. A.,Giasuddin,I.M., and Bhuiyan,A.A. 2011. Study on Isolation and Identification of Salmonella and Escherichia Coli from Different Poultry Feeds of Savar Region of Dhaka, Bangladesh.

7. Cui, Y., Wang,Q., Liu, S., Sun, R., Zhou,J. and Li,Y. 2017. Age-related variations in intestinal microflora of free-range and caged hens. Front. Microbiol. 8: article 1310 (10 pages).

8. Darwish, A.H, El-Sayiad, Gh.A., El-Maghawry, A.M., Mahrose, Kh.M. 2017. Growth performance, carcass traits and some blood parameters of broiler chicks as affected by housing system. Zagazig J. Agric. Res 44 (4).

9. El-kholy, M. S., El-hindawy, M. M., Alagawany, M., Abd El-Hack, M. E. and El-Sayed, S. E. A. 2017. Dietary supplementation of chromium can alleviate negative impacts of heat stress on performance, carcass yield, and some blood hematology and chemistry indices of growing Japanese quail. Biol Trace Elem Res 179(1):148-157.

10. Emokaro, C. O. and Eweka, K., 2015. A Comparative analysis of profitability of broiler production systems in Urban areas. J. Appl. Sci. Environ. Manage 19 (4): 627-31.

11. Ezekiel, C.N., Olarinmoye, A. O., Remo, I., State,O., Mofoluwaso, J. and Oyinloye, A. 2011. Distribution, antibiogram and multidrug resistance in Enterobacteriaceae from commercial poultry feeds in Nigeria no. African Journal of Microbiology Research 5(3):294-301

12. Faitarone, ABG, AC Pavan, C Mori, LS Batista, RP Oliveira, EA Garcia, CC Pizzolante, AA Mendes, and MR Sherer. 2005. Economic traits and performance of italian quails reared at different cage stocking densities. Revista Brasileira de Ciência Avícola 7 (1): 19-22.

13. FAO 2013. Poultry housing and management in developing countries. Poultry development review. Food Agricultural Organization 1-5. ISBN 978-92-5-108067-2

14. García, C.J., Soriano, M., and Benítez, V. 2020. Assessment of Salmonella spp . in feces, cloacal swabs, and eggs (eggshell and content separately) from a laying hen farm. Poultry Science 90(7):1581-5

15. Jones, D. R., Cox, N. A., Guard, J., Buhr, R. J., Gast, R. K. and Abdo, Z. 2015. Microbiological impact of three commercial laying hen housing systems. Poultry Science 94(3): 544-551

16. Kei, S. 1978. Serum lipid peroxide in cerebrovascular disorders determined by a new colorimetric method. Clinica Chimica Acta 90 (1): 37-43.

17. Li, Jianhui, Miao, Z, Tian,W., Yang,Y., Wang,J., and Yang,Y. 2017. Effects of different rearing systems on growth, small intestinal morphology and selected indices of fermentation status in broilers, Animal Science Journal 88: 900-908

18. Mahmoud, M. 2014. Effect of Chinese propolis supplementation on ross broiler chicks : microbial population in fecal matter and litter. Journal of Advanced Veterinary Research 4 (2): 77-84.

19. Mancini, G., Carbonara, A. O. and Heremans. J. F. 1965. Immunochemical quantitation of antigens by single radial immunodiffusion. Immunochemistry 2 (3): 235-IN6

20. Moravej, H. 2012. Withdrawal or reduction of the dietary vitamin premix on bone parameters of broiler chickens in two rearing systems withdrawal or reduction of the dietary vitamin premix on bone parameters of broiler chickens in two rearing systems. South African Journal of Animal Science 42: 169-177.
21. NRC: Nutrients requirements of poultry, 1994. 9th revised Ed. National Academy Press. Washington, D.C., USA.

22. NRC: National Research Council, 2011. Guide for the Care and Use of Laboratory Animals, eighth ed. National Academies Press.

23. Nwogor, U. A., and Ifeyinwa, E.C., 2017. The Effect of moringa oleifera on the growth performance, packed cell volume (PCV) and laying capacity of young growing quails. American Journal of Zoological Research 5 (2): 33-37.

24. Padmakumar, B., Nair, G.r., Ramakrishnan, A., Unni, A. K K., and Ravindranathan, N. 2000. Effect of floor density on production performance of Japanese quails reared in cages and deep litter. Journal of Veterinary and Animal Sciences, 31: 37-39.

25. Razee, A., Mahbub, A.S.M., Miah, M.Y., Hasnath, M.R., Hasan, M.K., Uddin, M.N. and Belal, S.A. 2016. Performance of Japanese quails (Coturnix Coturnix Japonica) on floor and cage rearing system in Sylhet, Bangladesh: Comparative Study. Iranian Journal of Applied Animal Science 6: 931-36.

26. Rosemary C, O., Sylvester C,U.M Juliet C,O. and Ugwu Okechukwu, P. C. 2013. Isolation and characterization of bacteria that are associated with the production and spoilage of Ogi (Akamu). International Journal of Pharm Medicine and Biological sciences 2(3): 79-85

27. Santhosh, B. and Singh, N. 2007. Guidelines for water quality management for fish culture in Tripura. ICAR Research Complex for NEH Region, Tripura Center, 29. https://www.scirp.org/(S(351jmbntvnsjt1 aadkposzje))/referen ce/ReferencesPapers.aspx?ReferenceID=2092317.

28. Shehata, F.S., Kamel, E.R., Abo-Salem, M.E. and Atallah, S. T. 2018. "Effect of some dietary supplementation on economic efficiency of growing Japanese quails." Benha Veterinary Medical Journal 34 (1): 219-231.

29. Simşek, Ü.C., Erișir,M., Ciftçi,M. and Seven,P.T. 2014 Effects of cage and floor housing systems on fattening performance, oxidative stress and carcass defects in broiler chicken. Kafkas Universitesi Veteriner Fakultesi Dergisi 20 (5): 727-733.

30. Sinha, A.K. (1972). Colorimetric assay of catalase. Analytical Biochemistry 47: 389

31. SPSS (2007) SPSS version 16.0. Chicago, IL: SPSS Incorporated.

32. Sugiharto, S. 2016. Role of Nutraceuticals in Gut Health and Growth Performance of Poultry. Journal of the Saudi Society of Agricultural Sciences 15 (2): 99-111.

33. Surai, P. F., and Fisinin, V. I. 2014. Selenium in poultry breeder nutrition: An update. Animal Feed Science and Technology 191: 1-15.

34. Trawińska, B. Chmielowiec-korzeniowska,A. and Nowakowicz-dębek, B. 2016. Revista Brasileira de Zootecnia Short Communication. Evaluation of microbial contamination of feces and soil on a laying-hen farm depending on sampling site and season. 45 (4): 190-194.

35. Willis, W. L. Murray, C. and Talbott, C. 2001. Campylobacter isolation trends of cage versus floor broiler chickens: A One-Year Study. Poultry Science 81 (5): 62931.

36. Yan, L., Lv, Z. Z., , An, S., Xing, K.,Wang, Z. G,, Lv, M. B. Choct, M., Guo, Y. M. and Zhou, G. L. 2020. Effects of rearing system and narasin on growth performance, gastrointestinal development, and gut microbiota of broilers. Poultry Science 100 (3): 100840. 